\title{
Hydrogen Production and Organic Synthesis in Photocatalytic Membrane Reactors: A Review
}

\author{
Cristina Lavorato, Pietro Argurio* and Raffaele Molinari
}

\author{
Department of Environmental Engineering, University of Calabria, Via P. Bucci, 44/A, I-87036 Rende (CS), \\ Italy
}

\begin{abstract}
Photocatalytic Membrane Reactors (PMRs) are green and promising technologies for sustainable applications. The recent scientific literature on PMRs is reviewed with a particular focus on the photocatalytic hydrogen production from water splitting, $\mathrm{CO}_{2}$ conversion to solar fuels $\left(\mathrm{CH}_{3} \mathrm{OH}, \mathrm{C}_{2} \mathrm{H}_{5} \mathrm{OH}, \mathrm{CH}_{4}\right.$ and $\left.\mathrm{HCOOH}\right)$ and organic synthesis such as oxidation (benzene to phenol, cyclohexane to cyclohexanol, ferulic acid to vanillin) and reduction reactions (acetophenone to phenylethanol). Different types of PMRs, synthesis of various photocatalytic membranes and modification of some semiconductors, to improve selectivity and yield also under visible light, are discussed. The described results show that combination of photocatalysis and a membrane process to build PMRs is a promising approach in view of large-scale application and use of solar energy.
\end{abstract}

Keywords: Photocatalytic membrane reactors, Photocatalysis, Hydrogen production, Photocatalytic water splitting, Organic synthesis, Photocatalytic reductions, Photocatalytic oxidations.

\section{INTRODUCTION}

Traditional industrial processes for making chemicals, often do not meet the current requirements for sustainability in terms of resources, environmental impact and energy efficiency, which are necessary characteristics for a "green" process [1]. Indeed, they frequently use toxic and hazardous substances as catalysts or solvents [2-4]. Thus, the development of innovative environmentally friendly chemical technologies and processes has become one of the most important challenge for chemical researchers in the last decades [5].

Heterogeneous photocatalysis is a chemical process which can be classified in the category of the so-called advanced oxidation processes (AOPs). It is based on the use of light, as driving force for chemical reactions, and of a semiconductor (the photocatalyst) to generate the oxidizing/reducing species. This process has been extensively used in the last four decades, since 1972 when Fujishima and Honda [6] discovered the photocatalytic water splitting of water on $\mathrm{TiO}_{2}$ electrodes.

The main advantage of photocatalysis, making it a potentially greener process, is the photonic activation mode of the photocatalyst [7] which creates, in the electronic structure of these miconductor, a conduction band (CB) and a valence band (VB), separated by a

"Address correspondence to this author at the Department of Environmental Engineering, University of Calabria, Via P. Bucci, 44/A, I-87036 Rende (CS), Italy; Tel: +39 0984 494015;

E-mail: pietro.argurio@unical.it band gap of energy $(\mathrm{Eg})$. When photons with energy (hv) equal to or higher than the band gap energy level (Eg) excited semiconductors, valence electron $\left(\mathrm{e}^{-}\right)$ pass from $V B$ to $C B$, giving the formation of a positive hole $\left(\mathrm{h}^{+}\right)$in the VB. The so produced electron/hole couple can undergo two different fates: i) the couple can quickly recombine releasing the accumulated energy as heat or photons; ii) the couple can migrate to the surface of the semiconductor where the promoted electron and the hole can, respectively, reduce and oxidize the adsorbed substrates.

Photocatalytic processes permit to operate catalytic processes under mild operating conditions (ambient temperature and pressure) in short reaction times by using very few auxiliary additives [8, 9]. Besides, photocatalysis avoids the use of strong oxidants/reducing agents and of heavy metal catalysts, by using safer photocatalysts (e.g. $\left.\mathrm{TiO}_{2}\right)$ [10]. Furthermore, photocatalysis permits the use of renewable solar energy, which is an important feature in terms of global sustainability [11, 12], and it can be combined with other physical and chemical technologies (e.g. membrane separations). These characteristics give good changes to meet the principles of green chemistry.

Because the photogenerated active species are capable to fully degrade (i.e. mineralize) efficiently almost every organic pollutant, in the last decade photocatalytic processes have been mainly applied in the field of environmental remediation [13-15]. Despite that, in last decade some studies have been carried out on the application of photocatalysis for synthesis such 
as selective reduction and oxidation [16-18], hydrogen production [19-21] and $\mathrm{CO}_{2}$ conversion [22, 23] to develop, in perspective, environmentally benign synthetic processes. These studies demonstrated that interesting selectivity can be obtained by using photocatalytic processes in comparison to conventional methods by appropriately selecting some photocatalytic parameters (e.g. semiconductor surface, excitation wavelength, etc.).

In view of large-scale application of photocatalysis it is important not only increase the overall process efficiency (quantum efficiency, product yield, etc.), but also to efficiently recover the photocatalyst from the reaction environment [24, 25]. Photocatalytic Membrane Reactors (PMRs) represent a very promising approach to obtain this requirement.

A PMR is a device, which couples photocatalysis and membrane separation to obtain a synergistic effect in a system where the chemical transformation, the recovery and reuse of the photocatalyst, the separation of substances from the treated solution and/or the recovery of the reaction products occur simultaneously. Thus, it can be affirmed that the implementation and use of PMRs represents a promising approach in view of large-scale application of photocatalysis.

Two main configurations of PMRs can be distinguished, depending on photocatalyst accommodation: i) the so-called slurry photocatalytic membrane reactors, where the photocatalyst is suspended in the reaction mixture; ii) the PMRs with photocatalyst immobilized in/on a substrate acting as a membrane (photocatalytic membrane). These configurations present specific limitations and advantages depending on the specific application.

The present work gives a critical overview of the recent state-of-the art of PMRs in hydrogen production, $\mathrm{CO}_{2}$ conversion and organic synthesis with a particular focus on the scientific literature of the last years. Some case studies are also discussed in the field of photocatalytic hydrogen production, photocatalytic $\mathrm{CO}_{2}$ conversion to valuable products and photocatalytic organic synthesis.

\section{HYDROGEN PRODUCTION FROM WATER SPLITTING IN PHOTOCATALYTIC MEMBRANE REACTORS}

In the last years, the interest for decreasing the dependence on fossil fuels increased. Currently, the main technologies for hydrogen production are (i) the steam reforming of hydrocarbons, (ii) the thermochemical processes in which hydrogen is released from organic materials such as fossil fuels and biomass using heat and chemical reactions, and (iii) the splitting of water into hydrogen and oxygen by electrolysis or solar energy [26].

In literature, high amount of hydrogen was produced by ethanol steam reforming (ESR). The bioethanol, is currently considered as green ethanol produced from biomass by biological processes. Almost $70 \%$ of the hydrogen produced during the bioethanol steam reforming reaction was recovered by lulianelli et al. [27] with a purity higher than $99 \%$ by using a membrane reactor for producing high grade hydrogen, reaching $60 \%$ of ethanol conversion (versus $40 \%$ of the equivalent conventional reactor) at $400{ }^{\circ} \mathrm{C}, 2.0$ bar and at space velocity of $1900 \mathrm{~h}^{-1}$.

Among the most sustainable methods for hydrogen production, today the water splitting by using solar energy is a very challenging approach. Photocatalytic water splitting is an important pathway for producing hydrogen, which is a promising alternative source of clean and renewable energy [28-33]. To achieve high hydrogen conversion efficiency under solar irradiation, various kinds of photocatalysts have been developed through reasonable engineering strategies. Recently the attention to develop PMRs combining photocatalytic water splitting with membrane separation has grown. Bipolar membranes (BPMs) have been used as efficient separators in water-splitting cells [28, 29 , 34]. BPMs consist of an anion-exchange membrane (AM) and a cation-exchange membrane (CM), that are permselective to anions and to cations, respectively, with an interfacial layer between them [35]. Catalysts have been included in the BPM interlayer to facilitate water dissociation, to reduce overpotential, and improve energy efficiency [36]. Inorganic nanomaterials are considered important catalysts to facilitate water dissociation. It is foreseen that these systems can help in planning new configurations of PMRs.

The most widely used semiconductor for photocatalysis is $\mathrm{TiO}_{2}$. Nevertheless, it is well-known that $\mathrm{TiO}_{2}$ photocatalyst is photoactive only in the UV range and its activity is strongly influenced by the recombination of photogenerated electrons and holes [4]. To limit these problems and to improve the photocatalytic activity, numerous strategies have been proposed by several authors such as the introduction of doping ions, the fabrication of nanostructured semiconductors for photocatalysis, including 
nanosheet, nanotube, and nanorod, various fabrication routes for $\mathrm{TiO}_{2}$ nanotubes such as hydrothermal, anodization, and template methods [37-41]. For this purpose, Hattori et al. developed an all-electrochemical technique for fabricating a bilayer structure made of a titanium dioxide $\left(\mathrm{TiO}_{2}\right)$ nanotube array (TNA) and a palladium film (TNA/Pd membrane). The Pd film was deposited by electroless plating on the TNA surface prepared by anodizing a titanium foil [38]. The authors reported that using the TNA/Pd membrane the amount of hydrogen produced per hour from the methanol/water mixture was estimated to be $0.37 \mathrm{~mol}$ $\mathrm{h}^{-1}$. The $\mathrm{H}_{2}$ production rate per unit area of the membrane was also calculated to be $0.21 \mathrm{~mol} \mathrm{~h}^{-1} \mathrm{~cm}^{-2}$ in the initial $2 \mathrm{~h}$ of UV illumination.

Another strategy to improve the $\mathrm{TiO}_{2}$ photocatalyst activity was reported, very recently, by Su et al. [39]. They used a new method, to allow the control of the pore size and doping level, that consists in the fabrication of $\mathrm{Al}$ - and $\mathrm{Zn}$-doped $\mathrm{TiO}_{2}$ nanotubes by atomic layer deposition (ALD) combined with polycarbonate $(\mathrm{PC})$ membrane as the template [40, 41]. The bilayers were alternately deposited on the $P C$ membrane template by ALD with various cyclic sequences. Results showed that, increasing the $\mathrm{Al}$ doping, charge recombination and hydroxide radical formation were improved, reducing the photocatalytic activity of $\mathrm{TiO}_{2}$. In contrast, the photocatalytic activity was enhanced at a $\mathrm{Zn}$ doping ratio of 0.01 , obtaining a hydrogen production rate from water splitting 6 times higher than that of commercial P25 $\mathrm{TiO}_{2}$ under UV light (2.66 mmol g ${ }^{-1} h^{-1}$ vs $0.45 \mathrm{mmol} \mathrm{g}^{-1} \mathrm{~h}^{-1}$ respectively).

In recent years, the development of new photocatalysts such as graphene quantum dots (GQDs) has attracted growing attention because of their high quantum effect and large specific surface areas [42]. Liu et al. [29] reported the fabrication of a sandwich $\mathrm{GQDs}-\mathrm{Cu}_{2} \mathrm{O} / \mathrm{BPM}$ with $\mathrm{GQDs}-\mathrm{Cu}_{2} \mathrm{O}$ catalyst inside the interlayer. The authors observed that GQDs$\mathrm{Cu}_{2} \mathrm{O}$ decreased membrane impedances under sunlight irradiation and that $\mathrm{GQDs}-\mathrm{Cu}_{2} \mathrm{O} / \mathrm{BPM}$ minimized $\mathrm{pH}$ gradient formation.

Very recently Zhong et al. [43] have designed and fabricated the first monolithic photomembrane of $\mathrm{CdS} / \mathrm{ZnO}$ nanocage arrays grown into the interspaces of multilayered reduced graphene oxide (rGO) nanosheets (CdS/ZnO/rGO). The monolithic $\mathrm{CdS} / \mathrm{ZnO} / \mathrm{rGO}$ photomembrane gave full advantage of the multiple roles of rGO nanosheets, such as photosensitizer, conductive medium, support and soft substrate, and guaranteed the intimate integration of $\mathrm{ZnO}$ with $\mathrm{CdS}$ and $\mathrm{rGO}$ in a well-defined architecture. The outstanding photocatalytic (PC) and photoelectrochemical (PEC) performances of the $\mathrm{CdS} / \mathrm{ZnO} / \mathrm{rGO}$ membrane mainly originates from the good integration of $\mathrm{CdS}, \mathrm{ZnO}$ and $\mathrm{rGO}$, resulting in the necessary light harvesting, efficient charge separation, charge transport and charge utilization of the overall PC process. It was found a photocatalytic $\mathrm{H}_{2}$ generation activity of $0.79 \mu \mathrm{mol} \mathrm{cm}^{-2} \mathrm{~h}^{-1}$ and a photocurrent response of $250 \mu \mathrm{A} \mathrm{cm} \mathrm{cm}^{-2}$ even under near-infrared light $(\lambda=700)$ irradiation, a striking feature rarely achieved in prior arts. Furthermore, multiple heterogeneous interfaces, such as $\mathrm{CdS} / \mathrm{ZnO}$ and $\mathrm{ZnO} / \mathrm{rGO}$, can also promote the separation of photogenerated charge carriers of rGO nanosheets and enhance rGO photoactivity.

Recently, Ratlamwala et al. [44] reported a parametric study performed to investigate the effects of variation in current density, temperature and electrode distance on hydrogen production rate, cost of hydrogen production and exergy efficiencies of the photoreactor. The hybrid photocatalytic hydrogen production reactor consisted of two half-cells under solar light irradiation. A mixture of $\mathrm{CuCl}, \mathrm{HCl}$, and water was fed to the anode half-cell in which titanium dioxide was used as electrode, $\mathrm{ZnS}$ was used as a photocatalyst and $\mathrm{Na}_{2} \mathrm{~S}$ was used as electron donor/hole scavenger. The positive hydrogen ions permeated through the membrane while electrons, through the electrical circuit, reached the second half-cell of the hybrid photocatalytic reactor (cathode side). The hydrogen production rate and hydrogen production cost

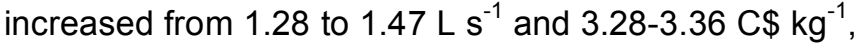
respectively, increasing the reactor temperature from 290 to $340 \mathrm{~K}$. Instead, the exergy efficiency of the hybrid photocatalytic hydrogen production reactor decreases from 5.25 to $3.9 \%$ at ambient temperature.

The use of solar energy in generating hydrogen comes with the benefits of low greenhouse gas emissions and low operation cost. The photocatalytic hydrogen production reactor studied by Marino et al. [45] described the one-step hydrogen and oxygen evolution through a PMR, which mimics the Z-scheme mechanism. Au/ $\mathrm{CeO}_{2}$ is used as photocatalyst leading to $\mathrm{O}_{2}$ formation via water oxidation, and $\mathrm{Au} / \mathrm{TiO}_{2}$ as photocatalyst, which promotes $\mathrm{H}_{2}$ formation via water reduction (Figure 1). The aqueous suspensions containing the two photocatalysts were separated by a membrane able to transport electrons via a redox 


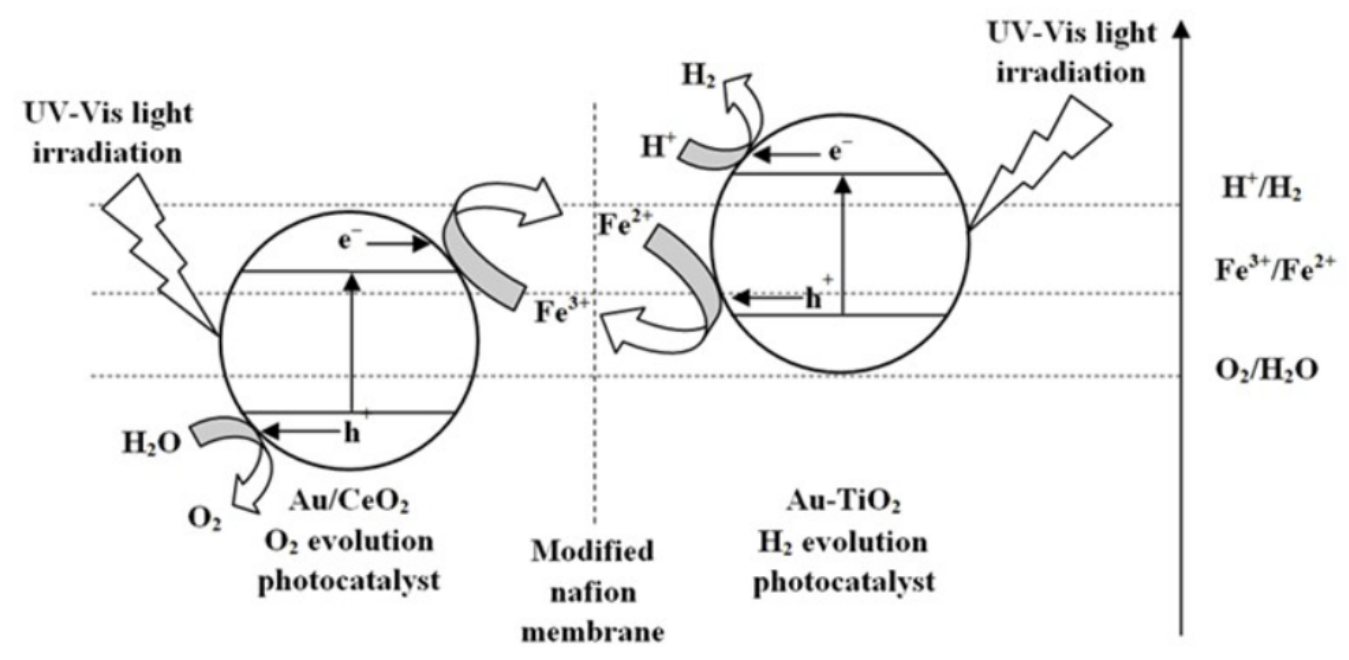

Figure 1: Diagram of the Z-scheme overall water splitting using $\mathrm{Au} / \mathrm{CeO}_{2}$ as a photocatalyst for oxygen generation, $\mathrm{Au} / \mathrm{TiO}{ }_{2}$ for hydrogen generation, and $\mathrm{Fe}^{3+} / \mathrm{Fe}^{2+}$ as a redox couple [45].

couple $\left(\mathrm{Fe}^{3+} / \mathrm{Fe}^{2+}\right)$ acting as an electron redox mediator. The authors reported that by using $5 \mathrm{mM}$ of $\mathrm{Fe}^{3+}$ concentration the best results in terms of hydrogen and oxygen evolution were obtained. Hydrogen and oxygen were produced in stoichiometric amounts under visible light irradiation. The optimal percentage of Auloading on titanium dioxide for hydrogen and oxygen generation was $0.25 \mathrm{wt}$. \%.

Su et al. used a twin reactor to separate evolution of hydrogen and oxygen during photocatalytic water splitting using a redox mediator in a Z-scheme approach (Figure 2) [46]. The separation of $\mathrm{H}_{2}$ and $\mathrm{O}_{2}$ evolution during the photocatalytic water splitting is very important because it avoids the explosion possibility due to direct contact of $\mathrm{H}_{2}$ and $\mathrm{O}_{2}$, and hydrogen-purification cost. Photocatalytic tests were carried out in a reactor divided by a Nafion membrane into two half-cells where $\mathrm{CuFeO}_{2}$ and $\mathrm{Bi}_{2} \mathrm{TiO}_{3}$ were employed as photocatalyst for hydrogen and oxygen generation, respectively. In this reactor, in addition to rGO, branched copper wires were included to facilitate electron transfer between the two photocatalysts. These photocatalysts were capable of extending the range of the visible-light for the overall water splitting. Instead, the role of rGO was as a collector extender for electron conduction in the Z-scheme photocatalytic water splitting system. Branched copper wires were employed to improve electron collection from the reduced graphene oxides in the twin reactor. The evolution rate of hydrogen and oxygen in this Zscheme was 2.23 and $1.14 \mathrm{mmol} \mathrm{h}^{-1}$, respectively, which is close to the stoichiometric ratio of 2:1.

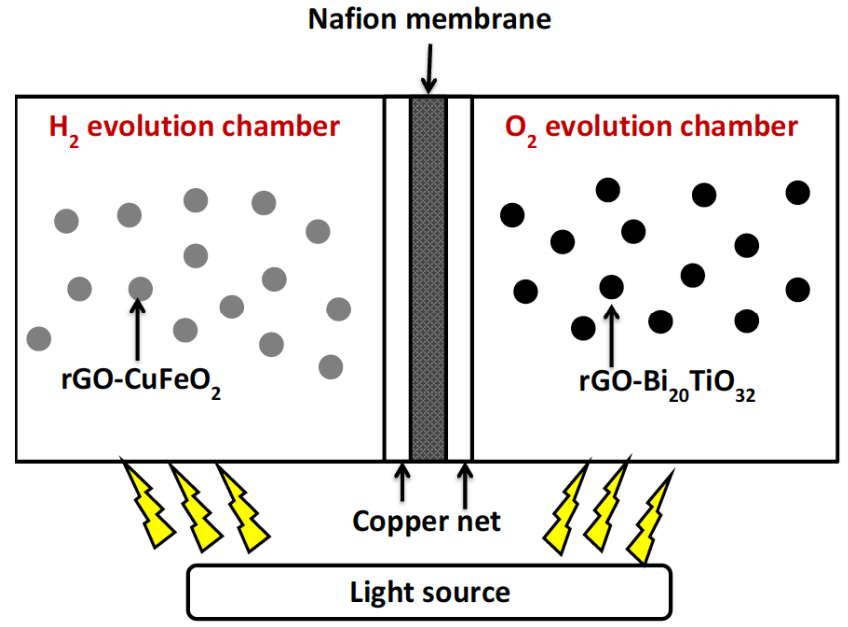

Figure 2: Conceptual Z-scheme of the twin reactor for overall water splitting reaction. Elaborated from ref. [46].

Other less recent methods for hydrogen production, present in literature, are summarized in the Table 1 and more details can be found in ref. [28].

\section{CONVERSION OF $\mathrm{CO}_{2}$ IN PHOTOCATALYTIC MEMBRANE REACTORS}

Membrane reactors technology represents a promising tool for the $\mathrm{CO}_{2}$ capture and reuse by conversion to valuable products. The reuse of emitted $\mathrm{CO}_{2}$ as a raw feedstock to promote energy bearing products is attracting considerable attention $[33,53-57]$.

In industry, $\mathrm{CO}_{2}$ is widely used for Sabatier reaction $[58,59]$ and reverse water-gas shift (RWGS) reaction. 
Table 1: Comparison of some Studied Photocatalytic Processes for $\mathrm{H}_{2}$ Production

\begin{tabular}{|c|c|c|c|c|c|}
\hline Type of Process & $\begin{array}{l}\text { Type of } \\
\text { Products }\end{array}$ & Type of Photocatalyst & Reactor Configuration & $\begin{array}{c}\text { Process Yield, } \\
\text { Productivity Selectivity }\end{array}$ & Reference \\
\hline $\begin{array}{l}\text { Photocatalytic water } \\
\text { splitting }\end{array}$ & $\mathrm{H}_{2}$ and $\mathrm{O}_{2}$ & $\begin{array}{c}\text { Z-scheme with } \mathrm{TiO}_{2} \text { and } \\
\mathrm{Pd} / \mathrm{TiO}_{2}\end{array}$ & $\begin{array}{l}\text { Two chambers slurry } \\
\text { photoreactor }\end{array}$ & $\begin{array}{c}.3 \text { and } 2.8 \mu \mathrm{mol} \mathrm{h}^{-1} \text { for } \\
\mathrm{O}_{2} \text { and } \mathrm{H}_{2}\end{array}$ & [47] \\
\hline $\begin{array}{c}\text { Photocatalytic } \\
\text { methanol oxidation }\end{array}$ & $\mathrm{H}_{2}$ & TiO2-Nafion-Pt & Photocatalytic membrane & $69 \mu \mathrm{L} \mathrm{h}^{-1} \mathrm{~cm}^{-2}$ & [48] \\
\hline $\begin{array}{l}\text { Photocatalytic water } \\
\text { splitting }\end{array}$ & $\mathrm{H}_{2}$ and $\mathrm{O}_{2}$ & $\mathrm{Pt} / \mathrm{SrTiO}_{3}: \mathrm{Rh}$ and $\mathrm{BiVO}_{4}$ & $\begin{array}{l}\text { Twin reactor system using } \\
\text { a Nafion membrane }\end{array}$ & $\begin{array}{l}0.65 \text { and } 0.32 \mu \mathrm{mol} \mathrm{h}{ }^{-1} \mathrm{~g}^{-1} \\
\text { of photocatalyst }\end{array}$ & [49] \\
\hline $\begin{array}{l}\text { Photocatalytic water } \\
\text { splitting }\end{array}$ & $\mathrm{H}_{2}$ and $\mathrm{O}_{2}$ & $\begin{array}{l}\mathrm{TiO}_{2} \text { thin film and } \mathrm{Pt} \\
\text { particles }\end{array}$ & $\begin{array}{l}\text { H-type photocatalytic } \\
\text { reactor }\end{array}$ & $\begin{array}{l}0.088 \text { and } 0.043 \mu \mathrm{mol} \mathrm{h} \mathrm{h}^{-1} \\
\text { for } \mathrm{H}_{2} \text { and } \mathrm{O}_{2}\end{array}$ & [50] \\
\hline $\begin{array}{l}\text { Photocatalytic water } \\
\text { splitting }\end{array}$ & $\mathrm{H}_{2}$ and $\mathrm{O}_{2}$ & $\mathrm{TiO}_{2}$ and $\mathrm{Pt}$ & $\begin{array}{l}\text { Two chamber } \\
\text { photocatalytic membrane } \\
\text { reactor }\end{array}$ & $\begin{array}{l}100 \text { and } 26 \mu \text { molh }^{-1} \text { for } \\
\mathrm{H}_{2} \text { and } \mathrm{O}_{2} \text { respectively }\end{array}$ & [51] \\
\hline $\begin{array}{l}\text { Photocatalytic water } \\
\text { splitting }\end{array}$ & $\mathrm{H}_{2}$ and $\mathrm{O}_{2}$ & $\mathrm{Ru} / \mathrm{SrTiO}_{3}: \mathrm{Rh}$ and $\mathrm{BiVO}_{4}$ & $\begin{array}{l}\text { Z-scheme photocatalytic } \\
\text { membrane reactor }\end{array}$ & $\begin{array}{l}110 \text { and } 43 \mu \mathrm{L} \mathrm{h}^{-1} \text { for } \mathrm{H}_{2} \\
\text { and } \mathrm{O}_{2} \text { respectively }\end{array}$ & [52] \\
\hline
\end{tabular}

Regarding the Sabatier reaction, $\mathrm{CO}_{2}$ reacts with $\mathrm{H}_{2}$ to form $\mathrm{CH}_{4}$ and $\mathrm{H}_{2} \mathrm{O}$ at $300-400{ }^{\circ} \mathrm{C}$. As for the RWGS reaction, $\mathrm{CO}_{2}$ firstly reacts with $\mathrm{H}_{2}$ to form $\mathrm{CO}$ and $\mathrm{H}_{2} \mathrm{O}$, then $\mathrm{CO}$ can be easily converted into hydrocarbons by the Fischer-Tropsch reaction. However, both reactions require high temperature and high pressure to reduce $\mathrm{CO}_{2}$ into hydrocarbons. Another way to reduce $\mathrm{CO}_{2}$ is the dry reforming of methane (DRM), which allows the conversion of $\mathrm{CO}_{2}$ producing syngas. Usually it occurs at $500-800{ }^{\circ} \mathrm{C}$ in presence of dehydrogenation catalysts such as $\mathrm{Ni}, \mathrm{Pt}, \mathrm{Ce}, \mathrm{Ru}$, etc [56]. The conversion of $\mathrm{CO}_{2}$ can be carried out also in electrochemical membrane reactors in which ion exchange membranes (IEMs) separate anode and cathode chambers. Despite the great potential, the electrochemical conversion of $\mathrm{CO}_{2}$ is still limited because the increase of the energy efficiency is primarily hindered by high over potentials for $\mathrm{CO}_{2}$ reduction. Moreover, significant technological progresses are still needed in order to make the $\mathrm{CO}_{2}$ conversion economically viable. There is growing concern for the development of efficient PMRs using renewable and sustainable energy sources, such as solar irradiation [60]. Photo-hydrogenation of carbon dioxide could convert $\mathrm{CO}_{2}$ by using solar energy under ambient temperature and pressure into desirable and sustainable solar fuels, such as methanol $\left(\mathrm{CH}_{3} \mathrm{OH}\right)$, methane $\left(\mathrm{CH}_{4}\right)$, and formic acid $(\mathrm{HCOOH})$ $[55,61]$. Methanol production is considered as a relevant advance over the existing literature results which mostly propose $\mathrm{CH}_{4}, \mathrm{CO}$ and $\mathrm{HCOOH}$, as the main reaction products of $\mathrm{CO}_{2}$ reduction [62]. The possibility of converting $\mathrm{CO}_{2}$ to liquid fuels has in fact a great potential because they can be stored and transported in easier way in comparison to gaseous fuels [63].

In recent years the photocatalytic reduction of $\mathrm{CO}_{2}$ has been widely studied by using different photocatalysts [64-70] immobilized into a polymeric membrane to improve the recovery of the catalyst and the control of the contact time between species in the solution and the catalyst.

Xiong et al. [71] studied the photocatalytic hydrogenation of $\mathrm{CO}_{2}$ into hydrocarbons by using $\mathrm{H}_{2}$ produced from photocatalytic water splitting in a novel twin reactor. Further modifications of the twin reactor were carried out in order to optimize the photocatalytic process in the gas and liquid phases. To improve the photo-hydrogenation performance in the reactor $\mathrm{Pt} / \mathrm{TiO}_{2}$ and $\mathrm{Cu} / \mathrm{TiO}_{2}$ were used as photocatalysts. The results indicated that $\mathrm{H}_{2}$ produced from water splitting effectively enhanced the $\mathrm{CO}_{2}$ hydrogenation in the gas phase by using $\mathrm{Pt} / \mathrm{TiO}_{2}$ and $\mathrm{Cu} / \mathrm{TiO}_{2}$ as photocatalysts.

A new type of material that can be used to synthesize membranes is a natural biopolymer such as chitosan. Zhao et al. prepared a $\mathrm{CdS} / \mathrm{NH}_{2}-\mathrm{UiO}-66$ hybrid membrane and tested it in the photocatalytic conversion of $\mathrm{CO}_{2}$ under visible light irradiation [57]. The highest, adsorption of $\mathrm{CO}_{2}$ obtained by using semiconductor/Metal-organic frameworks (MOFs) hybrid membrane caused an exceptional photocatalytic activity compared to the CdS membrane, $\mathrm{NH}_{2}$-UiO-66 membrane, and $\mathrm{CdS} / \mathrm{NH}_{2}-\mathrm{UiO}-66 /$ chitosan mixed powder. Moreover, by incorporating MOFs and semiconductors into membranes the transfer of 
electrons and inhibition of the recombination of electron-hole pairs in the hybrid membrane, enhances the activity for the $\mathrm{CO}_{2}$ photocatalytic reduction.

Metal organic frameworks (MOFs) have recently gained attention as potential alternatives to $\mathrm{TiO}_{2}$ catalysts, due to their high porosity and surface area, and good adsorption capacities for $\mathrm{CO}_{2}$ [72-75]. Maina et al. [72] studied a membrane reactor utilizing semiconductor nanoparticles and MOF for $\mathrm{CO}_{2}$ conversion. Semiconductor nanoparticles-doped ZIF-8 membrane reactors were fabricated using rapid thermal deposition (RTD), and their photocatalytic efficiency toward $\mathrm{CO}_{2}$ conversion was investigated under UV light. They demonstrated that the $\mathrm{TiO}_{2}$ and $\mathrm{Cu}-\mathrm{TiO}_{2}$ doped ZIF-8 membrane exhibited higher catalytic efficiency toward $\mathrm{CO}_{2}$ conversion as compared to the pristine ZIF-8 membrane (methanol yield increased by $70 \%$ ), and the product yield can be controlled depending on the composition and the dosage of the semiconductor nanoparticles.

Conversion of $\mathrm{CO}_{2}$ usually produces a mixture of products that may include methanol, carbon monoxide, methane among others. Very recently Maina et al. [53] studied the photo/electrocatalytic conversion of carbon dioxide by controlling the selectivity of the process to yield a specific product. For this purpose, the authors used metal organic frameworks (MOFs) derived carbon catalysts that had the potential to facilitate selective $\mathrm{CO}_{2}$ conversion, thanks to their regular microporous structure, and to enhance chemical stability and electrical conductivity as compared to the precursor MOFs. MOF-derived hybrid carbon photoelectrocatalytic reactors were fabricated on the surface of macroporous metal support, by direct carbonization of the metal supported MOF membranes. The electrocatalytic performance increased with the carbonization. Samples carbonized at $700{ }^{\circ} \mathrm{C}$ produced up to 9 times higher methanol yield as compared to non-carbonized membranes. By exchanging between electrocatalysis and photocatalysis, the product selectivity could also be tuned from methanol, to $\mathrm{CO}$ or a mixture of both.

Chen et al. [61] studied the photo-reduction of $\mathrm{CO}_{2}$ over 1 wt. \% Pt/CuAlGaO 4 photocatalyst under different $\mathrm{H}_{2}$ partial pressures. The products obtained were: methanol in major amount in the liquid and gas-liquid phases and methane that was the only product in the gaseous phase. The maximum total hydrocarbons amount $\left(8.302 \mu \mathrm{mol} \mathrm{g}{ }^{-1}\right)$ was achieved by operating in the gas-liquid phase.
Another approach to convert $\mathrm{CO}_{2}$ into liquid fuels such as methanol and ethanol was studied by Pomilla et al. [76] by using a photocatalytic membrane with exfoliated $\mathrm{C}_{3} \mathrm{~N}_{4}$ incorporated into a Nafion matrix. The photocatalytic tests were conducted in a PMR under UV-VIS irradiation. The photocatalytic membrane was used in a continuous photocatalytic reactor by using $\mathrm{H}_{2} \mathrm{O}$ as reducing agent. The membrane module was continuously fed with $\mathrm{CO}_{2}$ and $\mathrm{H}_{2} \mathrm{O}$ by means of a mass flow controller and an HPLC pump, respectively. The authors reported that the PMR converted at least 10 times more carbon than the system without the membrane. These results were ascribed to the better dispersion of the photocatalyst, which was embedded in the Nafion matrix. Alcohol production was promoted by the low contact time obtained thanks to the fast removal of the reaction mixture from the reacting volume, which limited oxidation and/or secondary reactions. On the contrary, the slow removal caused a partial oxidation of $\mathrm{MeOH}$ and $\mathrm{EtOH}$, favoring $\mathrm{HCHO}$ production. In all cases, a water defect corresponded to a larger $\mathrm{HCHO}$ production, reaching a flow rate of 27 $\mu$ mol g catalyst $^{-1} \mathrm{~h}^{-1}$ at a $\mathrm{H}_{2} \mathrm{O} / \mathrm{CO}_{2}$ feed molar ratio equal to 0.5 . The highest $\mathrm{MeOH}$ and $\mathrm{EtOH}$ selectivity were $54.6 \%$ and $45.4 \%$, respectively, at $\mathrm{H}_{2} \mathrm{O} / \mathrm{CO}_{2}$ feed molar ratio equal to 5 and contact time of $2 \mathrm{~s}$. Alcohol $(\mathrm{MeOH}$ $+\mathrm{EtOH})$ production rate of $32.8 \mu \mathrm{mol} \mathrm{g}_{\text {catalyst }}{ }^{-1} \mathrm{~h}^{-1}$ was obtained at the best operating conditions.

A new PMR system for the synthesis of methanol from $\mathrm{CO}_{2}$ was developed by Chakrabortty et al. [54]. They studied a novel membrane integrated scheme using a new generation graphene (hydrogen exfoliation graphene (HEG)) based nanocomposite materials. Simultaneous catalyst recycling was obtained by using a flat-sheet cross flow membrane integrated system. This system permitted to obtain high yield methanol production with a maximum productivity. A heterogeneous photocatalyst was developed by using a sono-chemical assisted sol-gel method by maintaining a weight ratio of 1:2:3 for hydrogen exfoliation graphene, titanium oxide and copper sulphate.

Methanol synthesis and purification were carried out in a commercially fabricated stirred set annular type Pyrex reactor enabling 250-Watt high pressure UV lamp. The designed lamp permitted to perform the photocatalytic reduction experiments in batch mode at three different wavelengths, i.e. 250, 305 and $365 \mathrm{~nm}$. The photocatalyst was kept suspended in $500 \mathrm{ml}$ of deionized (DI) water. The membrane assisted downstream was performed in flat-sheet cross-flow 
microfiltration modules with effective separation surface area of $0.01 \mathrm{~m}^{2}$ for each membrane. The permeation of the product stream along with photocatalyst content through membrane module was promoted by using a peristaltic pump.

Approximately, a productivity of $134 \mathrm{~g} \mathrm{~L}^{-1} \mathrm{~h}^{-1}$ and a yield of $40 \mathrm{mg} \mathrm{g}_{\mathrm{cat}}{ }^{-1}$ were found after $3 \mathrm{~h}$ of illumination under UV in the annular type Pyrex reactor at an optimum catalyst dosage of $10 \mathrm{~g} \mathrm{~L}^{-1}, \mathrm{CO}_{2}$ flow rate of 3 $\mathrm{L} \mathrm{min}^{-1}, \mathrm{pH}$ of 3 , and process temperature of $50{ }^{\circ} \mathrm{C}$. HEG not only enhanced the photo catalytic activity as well as increased the ability of adsorption of feed substrate through its high surface area. An appropriate choice of the cross flow microfiltration membranes in flat-sheet modules allowed catalyst recycle and first stage product purification.

In a recent work, Alsayegh et al. [55] presented a new approach that permitted to produce methanol by direct hydrogenation of $\mathrm{CO}_{2}$ using $\mathrm{H}_{2}$ produced by photocatalytic water splitting. The conceptual scheme of the process consisted of four units: a $\mathrm{CO}_{2}$ capture unit, a photocatalytic reactor, a membrane separation unit, and a methanol synthesis loop based on direct $\mathrm{CO}_{2}$ hydrogenation. In this study hydrogen is produced in a photoreactor without membrane which is used, instead, to separate hydrogen from oxygen. Despite this work does not describe a PMR process, the developed techno-economic analyses clearly identify the potential of integrated carbon dioxide capture and reuse and renewable feedstock production to produce value-added commodity chemicals and highlights the opportunities for the scientific community to advance the field.

Other less recent methods, present in literature for $\mathrm{CO}_{2}$ conversion, are summarized in Table 2 and more details can be found in ref. [76].

\section{ORGANIC SYNTHESES IN PHOTOCATALYTIC MEMBRANE REACTORS}

The recent review literature is very poor on this subject. Below the state of the art of few papers present in literature in the last years is reported. Considering that traditional industrial processes employed for the synthesis of organic substances are becoming unsustainable in terms of resources and environmental impact, in the last years the application of photocatalytic reactions to organic synthesis has attracted high interest $[4,25,33,60,80-83]$.

An important oxidation reaction widely studied in photocatalysis is the benzene oxidation to phenol. Despite phenol is an important chemical intermediate for the synthesis of petrochemicals, agrochemicals, and plastics, this product is obtained principally by the three-step cumene process that represents some limitations due to the multi step character and the production of an explosive intermediate to manage (cumene hydroperoxide) [4, 25]. Several studies have been performed in recent years with the purpose to develop more efficient and environmentally benign processes [4, 24, 84-88]. To limit the above mentioned problems an alternative route is the phenol production by a one-step direct benzene photocatalytic-oxidation process. This is a "green process" because light and a photocatalyst are used to generate $\mathrm{OH} \cdot$ radicals to oxidize benzene $[4,25,88]$. The disadvantages of this reaction are that phenol is more reactive than benzene, and by-products can be formed [85, 88]. To limit this problem, some authors have used a PMR with the suspended photocatalyst to perform phenol separation simultaneously to the photocatalytic reaction [89].

Another interesting photocatalytic reaction of green chemistry is the cyclohexane oxidation to cyclohexanol (A) and cyclohexanone $(\mathrm{K})$ (the mixture of both is

Table 2: Comparison of some Existing Photocatalytic Processes for $\mathrm{CO}_{2}$ Conversion

\begin{tabular}{|c|c|c|c|c|}
\hline Photocatalyst & Type of Products & Reactor Configuration & $\begin{array}{l}\text { Productivity } \\
\mu \mathrm{mol} \mathrm{g}_{\text {catalyst }}{ }^{-1} \mathrm{~h}^{-1}\end{array}$ & Reference \\
\hline $\mathrm{C}_{3} \mathrm{~N}_{4} 3 \% \mathrm{Cu} / \mathrm{TiO}_{2}$ & $\mathrm{CH}_{3} \mathrm{OH}$ and $\mathrm{HCOOH}$ & batch & 102 & [77] \\
\hline $\begin{array}{c}\mathrm{C}_{3} \mathrm{~N}_{4} \text { embedded in a Nafion } \\
\text { membrane }\end{array}$ & $\mathrm{CH}_{3} \mathrm{OH}, \mathrm{C}_{2} \mathrm{H}_{5} \mathrm{OH}, \mathrm{HCHO}$, acetone & continuous & $\begin{array}{c}0.9-17.9 \\
0.3-14.9 \\
0-27 \\
0-1.8\end{array}$ & [76] \\
\hline $\begin{array}{c}\mathrm{TiO}_{2} \text { embedded in a Nafion } \\
\text { membrane }\end{array}$ & $\mathrm{CH}_{3} \mathrm{OH}$ & continuous & $12.6-45$ & [78] \\
\hline $\mathrm{Cdln}_{2} \mathrm{~S}_{4} / \mathrm{C}_{3} \mathrm{~N}_{4} 20 \mathrm{wt} \%$ & $\mathrm{CH}_{3} \mathrm{OH}$ & continuous & 42.7 & [79] \\
\hline
\end{tabular}


called KA oil) with the use of clean and low-cost molecular oxygen as the oxidant and solar light as the driving force [90]. The obtained products are important intermediates to fabricate nylon- 6 and nylon-66. To improve the photocatalytic system for cyclohexane oxidation, Zhao et al. [90] used a PMR with the Cdoped $\mathrm{Cr}_{2} \mathrm{O}_{3} / \mathrm{NaY}$ composite membrane supported on stainless steel mesh. They prepared C-doped $\mathrm{Cr}_{2} \mathrm{O}_{3}$ photocatalyst on the upper surface of $\mathrm{NaY}$ zeolite membrane using a chromium-containing MOF as precursor. This composite membrane included three layers with different functions: (i) the stainless-steel mesh, used as support, was at the bottom, (ii) the $\mathrm{NaY}$ membrane, used as adsorbent, was in the middle, (iii) and $\mathrm{C}$-doped $\mathrm{Cr}_{2} \mathrm{O}_{3}$ used as photocatalyst was on the top. The results showed a production rate of $\mathrm{KA}$ oil substantially enhanced using the $\mathrm{C}$-doped $\mathrm{Cr}_{2} \mathrm{O}_{3} / \mathrm{NaY}$ powders over the composite membrane compared to the photocatalytic activity of $\mathrm{C}$-doped $\mathrm{Cr}_{2} \mathrm{O}_{3}$. This enhancement was caused by the adsorption of the products on the $\mathrm{NaY}$ membrane with high surface areas and polarity.

A photocatalytic oxidation reaction, instead of the classical chemical routes, has been studied by many authors for the synthesis of vanillin that is widely used in food, cosmetic, pharmaceutical, nutraceutical and fine chemical industries [83, 91-96]. When photocatalysis is coupled with pervaporation (PV) the recovery of the product of the partial oxidation of the aromatic alcohol prevents its degradation, thus enhancing the rate, the selectivity and the yield.

Different $\mathrm{TiO}_{2}$ samples as photocatalysts were tested by Augugliaro et al. [83] in the photocatalytic oxidation of trans-ferulic acid, isoeugenol, eugenol or vanillyl alcohol to produce vanillin in aqueous medium. The used system for the photocatalytic tests was constituted by two different batch systems: cylindrical and annular photoreactor. In the photo-oxidation tests, conducted at room temperature, the selectivity to vanillin ranged from 1.4 to $21 \mathrm{~mol} \%$ with a transmembrane flux about $3.31 \mathrm{~g} \mathrm{~h}^{-1} \mathrm{~m}^{-2}$. The use of a non-porous PEBAX ${ }^{\circledR} 2533$ membrane allowed the complete removal of the heterogeneous photocatalyst. Vanillin vapors were recovered as crystals with a high degree of purity $(\geq 99.8 \%)$ by downstream freezing in a liquid nitrogen trap.

An interesting integrated photocatalytic/PV system, AROMA (Advanced Recovery and Oxidation Method for Aldehydes) process, was developed by CameraRoda et al. [93]. The results obtained in the integrated
photocatalytic/PV system, evidenced that coupling the photocatalytic oxidation with the PV unit permitted to obtain enhanced yield (6\% vs. $3.9 \%$ )and conversion (35\% vs. $22 \%$ ) compared to the ones obtained in batch without the membrane. In a more recent work, CameraRoda et al. [94] improved the membrane performances in the pervaporation reactor to enhance the vanillin yield by using PEBAX membranes. The enrichment factor of vanillin and the resistance to water permeation increased with the membrane thickness, on the contrary, the resistance to vanillin permeation remained low. The vanillin flux and the enrichment factor were improved by raising the temperature. The $\mathrm{pH}$ had a minor influence on the rejection of the substrate, which remained high also at low $\mathrm{pH}$, when the substrate in solution was not dissociated.

Among different chemical reactions, also reduction processes, such as the reduction of carbonyl compounds in the corresponding alcohols, have an important role in organic synthesis [4]. Despite this, only few works have performed until now on the use of a PMR in reduction reactions such as photocatalytic transfer hydrogenation of acetophenone (AP) [80-82].

The possibility to conduct reduction reactions in a PMR was studied very recently by Molinari et al. [81, 82]. Acetophenone was chosen as a model substrate for hydrogenation of aromatic ketones because its reduction product, phenylethanol, is used as a building block for the synthesis of bioactive compounds.

In view to develop a green and environmental benign process, the photocatalytic hydrogenation of acetophenone to phenylethanol was conducted in a photocatalytic membrane reactor by using water as solvent, formic acid as hydrogen and electron donor, commercial $\mathrm{TiO}_{2}$ and homemade $\mathrm{Pd} / \mathrm{TiO}_{2}$ as photocatalysts [82], under UV and visible light. Photocatalytic tests were performed in PMRs with different substrate addition methods, obtaining the best performance of this system when the acetophenone was used as both solvent and reactant (substrate). This PMR, schematized in Figure 3, consisted of a biphasic membrane contactor coupled with the batch photoreactor, with a volume of recirculating solution of $725 \mathrm{~mL}$, immersed in a thermostatic bath. The membrane contactor was constituted by two compartment cells (each one with a volume of $125 \mathrm{~mL}$ ) separated by a flat sheet polypropylene membrane. The first compartment contained the aqueous phase 


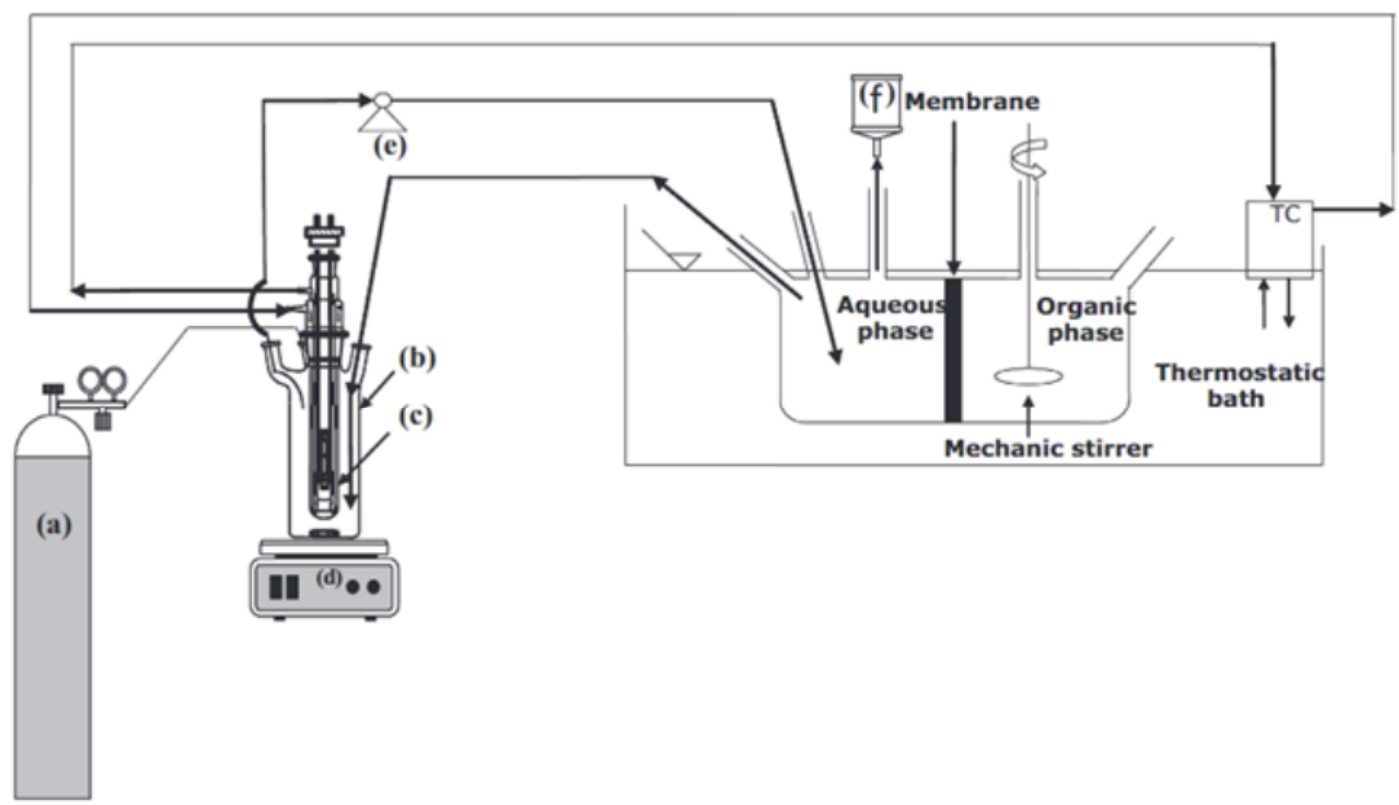

Figure 3: Scheme of the membrane contactor integrated with the batch photoreactor: (a) argon cylinder; (b) photoreactor; (c) medium pressure $\mathrm{Hg}$ lamp with cooling jacket; (d) magnetic stirrer; (e) peristaltic pump; (f) degassing system; (TC) temperature controller [82].

that was withdrawn from the photoreactor to the membrane contactor by means a peristaltic pump. Then, the aqueous phase returned back in the photoreactor by gravity. The second one contained acetophenone, acting as both the organic extracting phase and the substrate reservoir, maintained under mechanical stirring. The phenylethanol produced in the aqueous phase was preserved from successive overhydrogenation, with an improvement of process selectivity because it permeated through the membrane and then dissolved into the organic extracting phase. The use of a membrane extractor instead of a traditional liquid/liquid extraction unit prevent the physical mixing between the organic and the aqueous phases, and allowed a continuous extraction process.

The results showed that extraction of phenylethanol in the organic extracting phase simultaneously to the reaction, allowed an improvement of the efficiency of the photocatalytic reaction compared to the batch reactor (productivity $4.44 \mathrm{mg} \mathrm{g}^{-1} \mathrm{~h}^{-1}$ vs. $2.96 \mathrm{mg} \mathrm{g}^{-1}$ $\mathrm{h}^{-1}$ ), thus enhancing the process selectivity. The photocatalytic activity in the PMR under visible light irradiation was improved five times by a simple doping of the commercial $\mathrm{TiO}_{2}$ photocatalyst with $\mathrm{Pd}$, using deposition precipitation method (productivity $22.0 \mathrm{mg}$ $\mathrm{g}^{-1} \mathrm{~h}^{-1}$ ). In this PMR the separation was given by the distribution of a component between two immiscible phases, where the solubility of that component (phenylethanol) is different, for this reason it can be classified as an L-L membrane contactor.

To improve the heterogeneous transfer hydrogenation of AP under UV and visible light, in batch and in a membrane reactor, very recently, Lavorato et al. [81] synthetized different photocatalysts of $\mathrm{TiO}_{2}$-loaded faujasite (FAU) zeolite and $\mathrm{Pd} / \mathrm{TiO}_{2} / \mathrm{FAU}$. The photocatalytic activity of $\mathrm{FAU} \mathrm{TiO}_{2}$ samples was implemented extending the visible light activity by further modification by doping the photocatalyst with $\mathrm{Pd}$ by deposition precipitation method followed by chemical reduction. Then they were characterized by transmission electron microscopy (TEM), $\mathrm{N}_{2}$ adsorption-desorption at $77 \mathrm{~K}$ for specific surface (BET) area determination and atomic absorption spectroscopy (AAS). The activity of the synthesized photocatalysts, compared to bare and suspended FAU crystals as reference, was screened under visible and UV light in batch tests. Then the best samples were tested in the photocatalytic membrane reactor evaluating productivity, produced phenylethanol and extracted phenylethanol in the organic phase. The authors reported that the incorporation of $\mathrm{Pd}$ into a $\mathrm{TiO}_{2}$-functionalized faujasite framework not only improved the catalyst activity in the visible light region but enhanced also the absorption properties of the catalyst. Although the transition metal increases visible 
light utilization, the zeolite matrix acts as support for both $\mathrm{TiO}_{2}$ and $\mathrm{Pd}$ metal particles, which were homogeneously dispersed in the matrix and contributed to delay charges recombination by a mechanism of electron hopping within the framework. The final properties of the catalyst were strictly related both to the initial amount of $\mathrm{TiO}_{2}$ precursor used in the synthetic procedure and to the presence of solvent during the ion exchange process. The best results in terms of highly homogeneous dispersion of $\mathrm{TiO}_{2}$ semiconductor particles on the zeolite surface, highest BET area and porous volume values, were obtained in the sample TF10P, prepared by using the lowest amount of $\mathrm{TiO}_{2}$ precursor and isopropanol as solvent. Consequently, the TF10P sample showed the best performance in the batch photoreactor under UV light thanks to the synergic coupling of $\mathrm{TiO}_{2}$ and $\mathrm{FAU}$. This one was obtained with a homogeneous and stable dispersion of the photocatalyst on the support FAU particles, thus allowing a more effective utilization of light and the efficient charge-transfer to the substrate molecules. Doping the TF10P sample with Pd gave the photocatalyst Pd_TF10P which was active in the visible light. The productivity obtained in the membrane reactor was higher in this work compared to a previous work [82] of the same authors (productivity $99.6 \mathrm{mg}$ $\mathrm{gTiO}_{2}{ }^{-1} \mathrm{~h}^{-1}$ vs. $22 \mathrm{mg} \mathrm{gTiO}_{2}^{-1} \mathrm{~h}^{-1}$ ). The photocatalytic membrane reactor had an extraction percentage of phenylethanol from the reactive phase to the organic phase of ca. $25 \%$.

The results reported by Molinari et al. and Lavorato et al. [81, 82] evidenced that, by appropriately coupling the photocatalytic process with a membrane separation unit, increased system performance were achieved in terms of both overall efficiency and sustainability.

\section{CONCLUSION}

Photocatalytic processes can be applied to a wide range of substances in gaseous, solid or aqueous phase providing a "green" way for organic synthesis and hydrogen production. The photocatalytic hydrogen production from water splitting, the conversion of $\mathrm{CO}_{2}$ to solar fuels, photocatalytic oxidations for the synthesis of KA oil, vanillin and phenol and reduction reactions for the production of phenylethanol, described in this review, are some examples of different applications of photocatalytic membrane reactors developed in last years. In perspective, modification of various semiconductors and new preparation methods of photocatalysts and photocatalytic membranes, also of composite type, can improve the yield of the desired product and can increase the photocatalytic activity, also under visible light, allowing the use of renewable solar energy. Integration of the photocatalysis with a membrane process in the Photocatalytic Membrane Reactors (PMRs), with novel type of configurations, can improve the synergy of both technologies and make a potent technology to produce chemicals. Despite the recent literature is still poor on studies of PMRs in organic synthesis, the described oxidation and reduction reactions show that use of different types of PMRs, membranes and photocatalysts (as such or modified) permit to carry out organic reactions with improved system performance compared to the cases where the membrane is not used. The design and construction of photocatalytic membrane reactors for a wide range of practical applications, including hydrogen production from water splitting, $\mathrm{CO}_{2}$ conversion and organic synthesis, can open the way toward the industrial use of the solar radiation as energy source in chemical reactions using eco-friendly processes.

\section{REFERENCES}

[1] [1] Anastas PT, Warner JC. Green Chemistry, Theory and Practice. New York: Oxford University Press; 2000.

[2] Li J, Yang J, Wen F, Li C. A visible-light-driven transfer hydrogenation on CdS nanoparticles combined with iridium complexes. Chem Commun 2011; 47: 7080-7082. https://doi.org/10.1039/C1CC11800E

[3] Herrmann JM, Duchamp C, Karkmaz M, Thu Hoai B, Lachheb $\mathrm{H}$, Puzenat $\mathrm{E}$, et al. Environmental green chemistry as defined by photocatalysis. J Hazard Mater 2007; 146: 624-629. https://doi.org/10.1016/j.jhazmat.2007.04.095

[4] Molinari R, Lavorato C, Argurio P. Recent progress of photocatalytic membrane reactors in water treatment and in synthesis of organic compounds. A review. Catal Today 2017; 281: 144-164. https://doi.org/10.1016/j.cattod.2016.06.047

[5] Dai X, Shi F. Green synthesis of N-alkylamines and amides via the building and transformation of carbonyl-containing molecules. Curr Opin Green Sustain Chem 2020; 22: 1-6. https://doi.org/10.1016/j.cogsc.2019.11.001

[6] Fujishima A, Honda K. Electrochemical Photolysis of Water at a Semiconductor Electrode. Nature 1972; 238: 37-38. https://doi.org/10.1038/238037a0

[7] Herrmann JM. Heterogeneous photocatalysis: state of the art and present applications. Top Catal 2005; 34: 49-65. https://doi.org/10.1007/s11244-005-3788-2

[8] Moghaddas M. Removal of volatile organic compounds (VOCs) by photocatalytic oxidation - A review. Int J Pharm Res 2019; 11: 518-529.

https://doi.org/10.31838/ijpr/2019.11.01.069

[9] Freyria FS, Armandi M, Compagnoni M, Ramis G, Rossetti I, Bonelli B. Catalytic and photocatalytic processes for the abatement of $\mathrm{N}$-containing pollutants from wastewater. Part 2: Organic pollutants, J Nanosci Nanotechnol 2017; 17: 
3654-3672

https://doi.org/10.1166/jnn.2017.14014

[10] Konstantinou IK, Albanis $\mathrm{TA}$. $\mathrm{TiO}_{2}$-Assisted photocatalytic degradation of azo dyes in aqueous solution: Kinetic and mechanistic investigations: A review. Appl Catal B Environ 2004; 49:1-14

https://doi.org/10.1016/j.apcatb.2003.11.010

[11] Kumar A, Khan M, He J, Lo IMC. Recent developments and challenges in practical application of visible-light-driven $\mathrm{TiO}_{2}$-based heterojunctions for PPCP degradation: A critical review. Water Res 2020; 170: 115356. https://doi.org/10.1016/j.watres.2019.115356

[12] $\mathrm{Wu} \mathrm{S}$, $\mathrm{Hu} \mathrm{H}$, Lin $\mathrm{Y}$, Zhang $\mathrm{J}$, $\mathrm{Hu} \mathrm{YH}$. Visible light photocatalytic degradation of tetracycline over $\mathrm{TiO}_{2}$. Chem Eng J 2020; 382: 122842. https://doi.org/10.1016/i.cej.2019.122842

[13] Molinari R, Caruso A, Argurio P, Poerio T. Degradation of the drugs Gemfibrozil and Tamoxifen in pressurized and depressurized membrane photoreactors using suspended polycrystalline $\mathrm{TiO}_{2}$ as catalyst. J Membr Sci 2008; 319: 5463.

https://doi.org/10.1016/j.memsci.2008.03.033

[14] Yang L, Chen C, Hu Y, Wei F, Cui J, Zhao Y,et al. Threedimensional bacterial cellulose/polydopamine/ $/ \mathrm{TiO}_{2}$ nanocomposite membrane with enhanced adsorption and photocatalytic degradation for dyes under ultraviolet-visible irradiation. J Colloid Interf Sci 2020; 562: 21-28. https://doi.org/10.1016/j.jcis.2019.12.013

[15] $\mathrm{Hu} \mathrm{H}$, Lin $\mathrm{Y}, \mathrm{Hu} \mathrm{YH}$. Core-shell structured $\mathrm{TiO}_{2}$ as highly efficient visible light photocatalyst for dye degradation. Catal Today 2020; 341: 90-95. https://doi.org/10.1016/j.cattod.2019.01.077

[16] Zhi Y, Ma S, Xia H, Zhang Y, Shi Z, Mu Y, et al. Construction of donor-acceptor type conjugated microporous polymers: A fascinating strategy for the development of efficient heterogeneous photocatalysts in organic synthesis. Appl Catal B Environ 2019; 244: 36-44.

https://doi.org/10.1016/j.apcatb.2018.11.032

[17] Parrino F, Bellardita M, García-López El, Marcì G, Loddo V, Palmisano L. Heterogeneous Photocatalysis for Selective Formation of High-Value-Added Molecules: Some Chemical and Engineering Aspects. ACS Catal 2018; 8: 11191-11225. https://doi.org/10.1021/acscatal.8b03093

[18] Di Paola A, Bellardita M, Megna B, Parrino F, Palmisano L. Photocatalytic oxidation of trans-ferulic acid to vanillin on $\mathrm{TiO}_{2}$ and $\mathrm{WO}_{3}$-loaded $\mathrm{TiO}_{2}$ catalysts. Catal Today 2015; 252: 195-200. https://doi.org/10.1016/i.cattod.2014.09.012

[19] Li Y, Zhou X, Xing Y. In situ thermal-assisted loading of monodispersed $\mathrm{Pt}$ nanoclusters on CdSnano flowers for efficient photocatalytic hydrogen evolution. Appl Surf Sci 2020; 506: 144933. https://doi.org/10.1016/j.apsusc.2019.144933

[20] Li X, Ge Z, Xue F, Liu H, Lyu B, Liu M. Lattice-oriented contact in $\mathrm{Pd} / \mathrm{SrTiO}_{3}$ heterojunction for rapid electron transfer during photocatalytic $\mathrm{H}_{2}$ production. Mat Res Bull 2020; 123: 110722.

https://doi.org/10.1016/j.materresbull.2019.110722

[21] Guo Q, Zhao J, Yang Y, Huang J, Tang Y, Zhang X, et al. Mesocrystalline $\mathrm{Ta}_{3} \mathrm{~N}_{5}$ superstructures with long-lived charges for improved visible light photocatalytic hydrogen production. J Colloid Interf Sci 2020; 560: 359-368. https://doi.org/10.1016/j.jcis.2019.09.123

[22] Li K, Peng B, Peng T. Recent Advances in Heterogeneous Photocatalytic $\mathrm{CO}_{2}$ Conversion to Solar Fuels. ACS Catal 2016; 6: 7485-7527. https://doi.org/10.1021/acscatal.6b02089

[23] Khatun F, Aziz AA, Sim LC, Monir MU. Plasmonic enhanced Au decorated $\mathrm{TiO}_{2}$ nanotube arrays as a visible light active catalyst towards photocatalytic $\mathrm{CO}_{2}$ conversion to $\mathrm{CH}_{4}$. J Environ Chem Eng 2019; 7: 103233.

https://doi.org/10.1016/j.jece.2019.103233

[24] Loddo V, Bellardita M, Camera-Roda G, Parrino F, Palmisano L. Heterogeneous Photocatalysis: A Promising Advanced Oxidation Process. In Basile A, Mozia S, Molinari $\mathrm{R}$, editors. Current Trends and Future Developments on (Bio) Membranes-Photocatalytic Membranes and Photocatalytic Membrane Reactors. Amsterdam: Elsevier Inc. 2018; pp. 143.

[25] Molinari R, Argurio, P. PMRs in Photocatalytic Synthesis of Organic Compounds. In Basile A, Mozia S, Molinari R, editors. Current Trends and Future Developments on (Bio-) Membranes-Photocatalytic Membranes and Photocatalytic Membrane Reactors. Amsterdam: Elsevier Inc 2018; pp. 209231.

[26] Bellardita M, Camera-Roda G, Loddo V, Parrino F, Palmisano L. Coupling of membrane and photocatalytic technologies for selective formation of high added value chemicals. Catal Today 2020; 340: 128-144. https://doi.org/10.1016/j.cattod.2018.09.024

[27] Iulianelli A, Palma V, Bagnato G, Ruocco C, Huang $Y$, Veziroğlu NT, et al. From bioethanol exploitation to high grade hydrogen generation: Steam reforming promoted by a Co-Pt catalyst in a Pd-based membrane reactor. Renew Energ 2018; 119: 834-843. https://doi.org/10.1016/j.renene.2017.10.050

[28] Molinari R, Marino T, Argurio P. Photocatalytic membrane reactors for hydrogen production from water. Int $\mathrm{J}$ Hydrog Energy 2014; 39: 7247-7261.

https://doi.org/10.1016/j.ijhydene.2014.02.174

[29] Liu X, Jian X, Yang H, Song X, Liang Z. A photocatalytic graphene quantum dots- $\mathrm{Cu}_{2} \mathrm{O} /$ bipolar membrane as a separator for water splitting. New J Chem 2016; 40: 30753079.

https://doi.org/10.1039/C5NJ03604F

[30] Latorre-Sánchez M, Lavorato C, Puche M, Fornés V, Molinari $\mathrm{R}$, Garcia $\mathrm{H}$. Visible light photocatalytic hydrogen generation using dye-sensitized graphene oxide as photocatalyst Chemistry A European Journal 2012; 18: 16774-16783. https://doi.org/10.1002/chem.201202372

[31] Lavorato C, Primo A, Molinari R, García H. N-Doped Graphene Derived from Biomass as a Visible-Light Photocatalyst for Hydrogen Generation from Water/Methanol Mixtures. Chemistry A European Journal 2014; 20: 187-194. https://doi.org/10.1002/chem.201303689

[32] Lavorato C, Primo A, Molinari R, García H. Natural Alginate as a Graphene Precursor and Template in the Synthesis of Nanoparticulate Ceria/Graphene Water Oxidation Photocatalysts. ACS Catalysis 2014; 4: 497-504. https://doi.org/10.1021/cs401068m

[33] Molinari R, Lavorato C, Argurio P, Szymański K, Darowna D, Mozia S. Overview of Photocatalytic Membrane Reactors in Organic Synthesis, Energy Storage and Environmental Applications. Catalysts 2019; 3: 239. https://doi.org/10.3390/catal9030239

[34] Vargas-Barbosa NM, Geise GM, Hickner MA, Mallouk TE. Assessing the utility of bipolar membranes for use in photoelectro chemical water-splitting cells. Chem Sus Chem 2014; 7: 3017-3020. https://doi.org/10.1002/cssc.201402535

[35] Readi OMK, Kuenen HJ, Zwijnenberg HJ, Nijmeijer K. Novel membrane concept for internal $\mathrm{pH}$ control in electrodialysis of amino acids using a segmented bipolar membrane (sBPM). J Membr Sci 2013; 443: 219-226. https://doi.org/10.1016/j.memsci.2013.04.045

[36] Rajesh AM, Kumar M, Shahi VK. Functionalized biopolymer based bipolar membrane with poly ethylene glycol interfacial layer for improved water splitting. J Membr Sci 2011; 372: 
249-257.

https://doi.org/10.1016/j.memsci.2011.02.009

[37] Chiarello GL, Forni L, Selli E. Photocatalytic hydrogen production by liquid-and gas-phase reforming of $\mathrm{CH}_{3} \mathrm{OH}$ over flame-made $\mathrm{TiO}_{2}$ and $\mathrm{Au} / \mathrm{TiO}_{2}$. Catal Today 2009; 144: 69-74. https://doi.org/10.1016/j.cattod.2009.01.023

[38] Hattori M, Noda K. All electrochemical fabrication of a bilayer membrane composed of nanotubular photocatalyst and palladium toward high-purity hydrogen production. Appl Surf Sci 2015; 357: 214-220.

https://doi.org/10.1016/j.apsusc.2015.08.236

[39] Su CY, Wang LC, Liu WS, Wang CC, Perng TP. Photocatalysis and Hydrogen Evolution of Al- and Zn-Doped $\mathrm{TiO}_{2}$ Nanotubes Fabricated by Atomic Layer Deposition. ACS Appl Mater Interf 2018; 10: 33287-33295. https://doi.org/10.1021/acsami.8b12299

[40] Su CY, Wang CC, Hsueh YC, Gurylev V, Kei CC, Perng TP. Enabling High Solubility of $\mathrm{ZnO}$ in $\mathrm{TiO}_{2}$ by Nanolamination of Atomic Layer Deposition. Nanoscale 2015; 7:19222-19230. https://doi.org/10.1039/C5NR06264K

[41] Su CY, Wang CC, Hsueh YC, Gurylev V, Kei CC, Perng TP. Fabrication of Highly Homogeneous Al-doped $\mathrm{TiO}_{2}$ Nanotubes by Nanolamination of Atomic Layer Deposition. J Am Ceram Soc 2017; 100: 4988-4993. https://doi.org/10.1111/jace.15044

[42] Atienzar P, Primo A, Lavorato C, Molinari R, García H. Preparation of Graphene Quantum Dots from Pyrolyzed Alginate. Langmuir 2013; 29: 6141-6146. https://doi.org/10.1021/la400618s

[43] Zhong Y, Yang S, Cai X, Zhang S, Gao Q, Liu Y, et. al. Bioinspired multilayered graphene-directed assembly of monolithic photomembrane for full-visible light response and efficient charge separation. Appl Catal B Environ 2020; 263: 117587.

https://doi.org/10.1016/j.apcatb.2019.03.074

[44] Ratlamwala TAH, Dincer I. Energy and exergy analyses of hybrid photocatalytic hydrogen production reactor for $\mathrm{CueCl}$ cycle. Int J Hydrog Energ 2018; 43: 4167-4176. https://doi.org/10.1016/j.ijhydene.2017.12.138

[45] Marino T, Figoli A, Molino A, Argurio P, Molinari R. Hydrogen and Oxygen Evolution in a Membrane Photoreactor Using Suspended Nanosized $\mathrm{Au} / \mathrm{TiO}_{2}$ and $\mathrm{Au} / \mathrm{CeO}_{2}$. Chem Engineering 2019; 3: 5.

https://doi.org/10.3390/chemengineering3010005

[46] Su WN, Ayele DW, Chen HM, Pan CJ, Ochie V, Chiang KT, et al. A wireless and redox mediator-free Z-scheme twin reactor for the separate evolution of hydrogen and oxygen. Mater Today Energ 2019; 12: 208-214.

https://doi.org/10.1016/j.mtener.2019.01.009

[47] Fujihara K, Ohno T, Matsumara M. Splitting of water by electrochemical combination of two photocatalytic reactions on $\mathrm{TiO}_{2}$ particles. J Chem Soc Faraday Trans 1998; 94: 3705-3709.

https://doi.org/10.1039/A806398B

[48] Seger B, Kamat PV. Fuel cell geared in reverse: photocatalytic hydrogen production using a $\mathrm{TiO}_{2} / \mathrm{Nafion} / \mathrm{Ptmembrane}$ assembly with no applied bias. $\mathrm{J}$ Phys Chem C 2009; 113: 18946-18952. https://doi.org/10.1021/jp907367k

[49] Yu SC, Huang CW, Liao CH, Wu JCS, Chang ST, Chen KH. A novel membrane reactor for separating hydrogen and oxygen in photocatalytic water splitting. J Membr Sci 2011; 382: 291-299. https://doi.org/10.1016/j.memsci.2011.08.022

[50] Kitano M, Tsujimaru K, Anpo M. Decomposition of water in the separate evolution of hydrogen and oxygen using visiblelight-responsive $\mathrm{TiO}_{2}$ thin film photocatalysts: effect of the work function of the substrates on the yield of the reaction. Appl Catal A Gen 2006; 314: 179-183. https://doi.org/10.1016/j.apcata.2006.08.017

[51] Selli E, Chiarello GL, Quartarone E, Mustarelli P, Rossetti I, Forni L. A photocatalytic water splitting device for separate hydrogen and oxygen evolution. Chem Commun 2007; 2007: 5022-5024.

https://doi.org/10.1039/B711747G

[52] Sasaki $\mathrm{Y}$, Kato H, Kudo A. [Co(bpy $\left.)_{3}\right]^{3+/ 2+}$ and $\left[\mathrm{Co}(\text { phen })^{3}\right]^{3+/ 2+}$ electron mediators for overall water splitting undersunlight irradiation using Z-scheme photocatalyst system. J Am Chem Soc 2013; 135: 5441-5449. https://doi.org/10.1021/ja400238r

[53] Maina JW, Pozo-Gonzalo C, Schütz JA, Wang J, Dumée LF. Tuning $\mathrm{CO}_{2}$ conversion product selectivity of metal organic frameworks derived hybrid carbon photoelectrocatalytic reactors. Carbon 2019; 148: 80-90. https://doi.org/10.1016/j.carbon.2019.03.043

[54] Chakrabortty S, Nayak J, Pal P, Kumar R, Banerjee S, Mondal PK, et al. Catalytic conversion of $\mathrm{CO}_{2}$ to biofuel (methanol) and downstream separation in membrane integrated photoreactor system under suitable conditions. Int J Hydrog Energ 2020; 45: 675-690. https://doi.org/10.1016/j.ijhydene.2019.10.220

[55] Alsayegh S, Johnson JR, Ohs B, Wessling M. Methanol production via direct carbon dioxide hydrogenation using hydrogen from photocatalytic water splitting: Process development and techno-economic analysis. J Clean Prod 2019; 208: 1446-1458.

https://doi.org/10.1016/j.jclepro.2018.10.132

[56] Brunetti A, Fontananova E. $\mathrm{CO}_{2}$ Conversion by Membrane Reactors. J Nanosci Nanotechnol 2019; 19: 3124-3134. https://doi.org/10.1166/jnn.2019.16649

[57] Zhao H, Yang X, Xu R, Li J, Gao S, Cao R. CdS/NH $\mathrm{N}_{2}-U i O-66$ hybrid membrane reactors for the efficient photocatalytic conversion of $\mathrm{CO}_{2}$. J Mater Chem A 2018; 6: 20152-20160. https://doi.org/10.1039/C8TA05970E

[58] Lunde PJ, Kester FL. Rates of methane formation from carbon dioxide and hydrogen over a ruthenium catalyst. $J$ Catal 1973; 30: 423-429.

https://doi.org/10.1016/0021-9517(73)90159-0

[59] Thampi KR, Kiwi J, Gratzel M. Methanation and photomethanation of carbon dioxide at room temperature and atmospheric pressure. Nature 1987; 327: 506-508. https://doi.org/10.1038/327506a0

[60] Molinari R, Argurio P, Lavorato C. Review on reduction and partial oxidation of organics in Photocatalytic (Membrane) Reactors. Curr. Org. Chem. 2013; 17: 2516-2537. https://doi.org/10.2174/13852728113179990063

[61] Chen CY, Yu JCC, Nguyen VH, Wu JCS, Wang WH, Kocí K. Reactor Design for $\mathrm{CO}_{2}$ Photo-Hydrogenation towards Solar Fuels under Ambient Temperature and Pressure. Catalysts 2017; 7: 63 https://doi.org/10.3390/catal7020063

[62] Merino-Garcia I, Alvarez-Guerra E, Albo J, Irabien A. Electrochemical membrane reactors for the utilisation of carbon dioxide. Chem Eng J 2016; 305: 104-120. https://doi.org/10.1016/j.cej.2016.05.032

[63] Kimfung L, Xiaoqiang A, Park KH, Khraisheh M, Tang J. A critical review of $\mathrm{CO}_{2}$ photoconversion: Catalysts and reactors. Catal Today 2014; 224: 3-12. https://doi.org/10.1016/j.cattod.2013.12.006

[64] Lin W, Han $\mathrm{H}$, Frei $\mathrm{H}$. $\mathrm{CO}_{2}$ splitting by $\mathrm{H}_{2} \mathrm{O}$ to $\mathrm{CO}$ and $\mathrm{O}_{2}$ under UV light in TiMCM-41 silicate sieve. J Phys Chem B 2004; 108: 18269-18273.

https://doi.org/10.1021/jp040345u

[65] Qin G, Zhang $Y$, Ke X, Tong X, Sun Z, Liang M, et al. Photocatalytic reduction of carbon dioxide to formic acid, formaldehyde, and methanol using dye-sensitized $\mathrm{TiO}_{2}$ film. 
Appl Catal B Environ 2013; 129: 599-605. https://doi.org/10.1016/j.apcatb.2012.10.012

[66] Slamet H, Nasution HW, Purnama E, Kosela S, Lazuardi G. Photocatalytic reduction of $\mathrm{CO}_{2}$ on copper-doped titania catalysts prepared by improved-impregnation method. Catal Commun 2005; 6: 313-319. https://doi.org/10.1016/j.catcom.2005.01.011

[67] Mele G, Annese C, De Riccardis A, Fusco C, Palmisano L, Vasapollo G, et al. Turning lipophilic phthalocyanines $/ \mathrm{TiO}_{2}$ composites into efficient photocatalysts for the conversion of $\mathrm{CO}_{2}$ into formic acid under UV-vis light irradiation. Appl Catal A Chem 2014; 481: 169-172. https://doi.org/10.1016/j.apcata.2014.05.008

[68] Ichikawa S, Doi R. Hydrogen production from water and conversion of carbon dioxide to useful chemicals by room temperature photoelectrocatalysis. Catal Today 1996; 27: 271-277. https://doi.org/10.1016/0920-5861(95)00198-0

[69] Ola O, Maroto-Valer MM. Review of Material Design and Reactor Engineering on $\mathrm{TiO}_{2}$ Photocatalysis for $\mathrm{CO}_{2}$ Reduction. J Photochem Photobiol C 2015; 24: 16-42. https://doi.org/10.1016/j.jphotochemrev.2015.06.001

[70] Maina JW, Schütz JA, Grundy L, Des Ligneris E, Yi Z, Kong $\mathrm{L}$, et al. Inorganic Nanoparticles/Metal Organic Framework Hybrid Membrane Reactors for Efficient Photocatalytic Conversion of $\mathrm{CO}_{2}$. ACS Appl Mater Interfaces 2017; 9: 35010-35017.

https://doi.org/10.1021/acsami.7b11150

[71] Xiong Z, Kuang CC, Lin KY, Lei Z, Chen X, Gong B, et al. Enhanced $\mathrm{CO}_{2}$ photocatalytic reduction through simultaneously accelerated $\mathrm{H}_{2}$ evolution and $\mathrm{CO}_{2}$ hydrogenation in a twin photoreactor. $\mathrm{J} \mathrm{CO}_{2}$ Util 2018; 24: 500-508.

https://doi.org/10.1016/j.jcou.2018.02.006

[72] Maina JW, Pozo-Gonzalo C, Kong L, Schutz J, Hill M, Dumee LF. Metal Organic Framework Based Catalysts for $\mathrm{CO}_{2}$ Conversion. Mater Horiz 2017; 4: 345-361. https://doi.org/10.1039/C6MH00484A

[73] Wang D, Huang R, Liu W, Sun D, Li Z. Fe-Based Mofs for Photocatalytic $\mathrm{CO}_{2}$ reduction: Role of Coordination Unsaturated Sites and Dual Excitation Pathways. ACS Catal 2014; 4 : 4254-4260. https://doi.org/10.1021/cs501169t

[74] Zeng L, Guo X, He C, Duan C. Metal-Organic Frameworks: Versatile Materials for Heterogeneous Photocatalysis. ACS Catal 2016; 6: 7935-7947.

https://doi.org/10.1021/acscatal.6b02228

[75] Li Y, Xu H, Ouyang S, Ye J. Metal-Organic Frameworks for Photocatalysis. Phys Chem Chem Phys 2016; 18: 75637572. https://doi.org/10.1039/C5CP05885F

[76] Pomilla FR, Brunetti A, Marcì G, Garclá-Loṕez E, Fontananova $\mathrm{E}$, Palmisano $\mathrm{L}$, et al. $\mathrm{CO}_{2}$ to Liquid Fuels: Photocatalytic Conversion in a Continuous Membrane Reactor. ACS Sustain Chem Eng 2018; 6: 8743-8753. https://doi.org/10.1021/acssuschemeng. 8b01073

[77] Adekoya DO, Tahir $M$, Amin NAS. g- $\mathrm{C}_{3} \mathrm{~N}_{4} /\left(\mathrm{Cu} / \mathrm{TiO}_{2}\right)$ nanocomposite for enhanced photoreduction of $\mathrm{CO}_{2}$ to $\mathrm{CH}_{3} \mathrm{OH}$ and $\mathrm{HCOOH}$ under UV/visible light. $\mathrm{J} \mathrm{CO}_{2}$ Util 2017; 18: 261-274. https://doi.org/10.1016/j.jcou.2017.02.004

[78] Sellaro $M$, Bellardita $M$, Brunetti $A$, Fontananova $E$, Palmisano L, Drioli $\mathrm{E}$, et al. $\mathrm{CO}_{2}$ conversion in a photocatalytic continuous membrane reactor. RSC Adv 2016; 6: 67418-67427 https://doi.org/10.1039/C6RA06777H

[79] Liu H, Zhang Z, Meng J, Zhang J. Novel visible-light-driven $\mathrm{Cdln}_{2} \mathrm{~S}_{4} /$ mesoporous $\mathrm{g}-\mathrm{C}_{3} \mathrm{~N}_{4}$ hybrids for efficient photocatalytic reduction of $\mathrm{CO}_{2}$ to methanol. Mol Catal 2017; 430: 9-19.

https://doi.org/10.1016/j.molcata.2016.12.006
[80] Lavorato C, Argurio P, Molinari R. $\mathrm{TiO}_{2}$ and $\mathrm{Pd} / \mathrm{TiO}_{2}$ as Photocatalysts for Hydrogenation of Ketones and Perspective of Membrane Application. Int J Adv Res 2019; 1: 33-41.

http://dx.doi.org/10.20431/2349-0403.0601005

[81] Lavorato C, Argurio P, Mastropietro TF, Pirri G, Poerio T, Molinari R. $\mathrm{Pd} / \mathrm{TiO}_{2}$ doped faujasite photocatalysts for acetophenone transfer hydrogenation in a photocatalytic membrane reactor. J Catal 2017; 353: 152-161. https://doi.org/10.1016/j.jcat.2017.07.015

[82] Molinari R, Lavorato C, Argurio P. Photocatalytic reduction of acetophenone in membrane reactors under UV and visible light using $\mathrm{TiO}_{2}$ and $\mathrm{Pd} / \mathrm{TiO}_{2}$ catalysts. Chem Eng $\mathrm{J}$ 2015; 274: $307-316$ https://doi.org/10.1016/j.cej.2015.03.120

[83] Augugliaro V, Camera-Roda G, Loddo V, Palmisano G Palmisano L, Parrino $\mathrm{F}$, et al. Synthesis of vanillin in water by $\mathrm{TiO}_{2}$ photocatalysis. Appl Catal B Environ 2012; 111: 555561.

https://doi.org/10.1016/j.apcatb.2011.11.007

[84] Liu Y, Murata K, Inaba M. Direct oxidation of benzene to phenol by molecular oxygen over catalytic systems containing $\mathrm{Pd}(\mathrm{OAc})_{2}$ and heteropolyacid immobilized on HMS or PIM. J Mol Catal A Chem 2006; 256: 247-255. https://doi.org/10.1016/j.molcata.2006.05.015

[85] Molinari R, Argurio P, Poerio T. Vanadylacetylacetonate filled PVDF membranes as the core of a liquid phase continuous process for pure phenol production from benzene. J Membr Sci 2015; 476: 490-499. https://doi.org/10.1016/i.memsci.2014.12.006

[86] Niwa S, Eswaramoorthy $M$, Nair J, Raj A, Itoh $N$, Shoji $H$, et al. A one-step conversion of benzene to phenol with a palladium membrane. Science 2002; 295: 105-107. https://doi.org/10.1126/science.1066527

[87] Molinari R, Lavorato C, Poerio T. Performance of vanadium based catalyst in a membrane contactor for the benzene hydroxylation to phenol. Appl Catal A Gen 2012; 417: 87-92. https://doi.org/10.1016/j.apcata.2011.12.031

[88] Shimizu K, Akahane H, Kodama T, Kitayama Y. Selective photo-oxidation of benzene over transition metal-exchanged BEA zeolite. Appl Catal A Gen 2004; 26: 75-80. https://doi.org/10.1016/j.apcata.2004.04.001

[89] Molinari R, Caruso A, Poerio T. Direct benzene conversion to phenol in a hybrid photocatalytic membrane reactor. Catal Today 2009; 144: 81-86 https://doi.org/10.1016/j.cattod.2009.02.034

[90] Zhao X, Zhang Y, Qiu P, Wen P, Wang H, Xu G, et al. Cdoped $\mathrm{Cr}_{2} \mathrm{O}_{3} / \mathrm{NaY}$ composite membrane supported on stainless steel mesh with enhanced photocatalytic activity for cyclohexane oxidation. J Mater Sci 2018; 53: 6552-6561. https://doi.org/10.1007/s10853-018-1997-x

[91] Pickett-Baker J, Ozaki R. Pro-Environmental Products: Marketing Influence on Consumer Purchase Decision. J Consum Mark 2008; 25: 281-293.

https://doi.org/10.1108/07363760810890516

[92] Camera-Roda G, Augugliaro V, Cardillo A, Loddo V Palmisano G, Palmisano L. A pervaporation photocatalytic reactor for the green synthesis of vanillin. Chem Eng J 2013; 224: $136-143$ https://doi.org/10.1016/j.cej.2012.10.037

[93] Camera-Roda G, Santarelli F, Augugliaro V, Loddo V, Palmisano G, Palmisano L, et al. Photocatalytic process intensification by coupling with pervaporation. Catal Today 2011; 161: 209-213 https://doi.org/10.1016/j.cattod.2010.10.052

[94] Camera-Roda G, Santarelli F. Design of a Pervaporation Photocatalytic Reactor for Process Intensification. Chem Eng Technol 2012; 35: 1221-1228. https://doi.org/10.1002/ceat.201100687 
[95] Böddeker KW, Bengston G, Pingel H, Dozel S. Pervaporation of high boilers using heated membranes. Desalination 1993; 90: 249-257. https://doi.org/10.1016/0011-9164(93)80179-Q
Böddeker KW, Gatfield IL, Jähnig J, Schorm C. Pervaporation at the vapor pressure limit: Vanillin. J Membr Sci 1997; 137: 155-158.

https://doi.org/10.1016/S0376-7388(97)00187-7

Received on 28-12-2019

Accepted on 10-01-2020

Published on 01-02-2020

http://dx.doi.org/10.15379/2410-1869.2020.07.01.01

(c) 2020 Lavorato et al.; Licensee Cosmos Scholars Publishing House.

This is an open access article licensed under the terms of the Creative Commons Attribution Non-Commercial License

(http://creativecommons.org/licenses/by-nc/3.0/), which permits unrestricted, non-commercial use, distribution and reproduction in any medium, provided the work is properly cited. 